\title{
PENINGKATAN HASIL BELAJAR TEMA KEGEMARAN MENGGUNAKAN MODEL PEMBELAJARAN INTEGRATED PADA SISWA KELAS III SDN MANARAP TENGAH 1
}

\author{
Rohana \\ Sekolah Dasar Negeri Manarap Tengah 1, Kab. Banjar, Kalimantan Selatan \\ Email: rohana0110@gmail.com \\ Website: https://jurnal.uin-antasari.ac.id/index.php/adzka \\ Received: 10 Desember 2019; Accepted: 10 Januari 2020; Published: 12 Januari 2019
}

\begin{abstract}
The purpose of this study was to determine the implementation of Integrated which was achieved after the learning. Integrated learning as a strategy that facilitates students to search for, find concepts of knowledge in real or factual contexts but still under the guidance of the teacher. The main steps in Integrated learning activities are the presentation of the problem by the teacher, students establishing hypotheses, students collecting data through analyzing the findings data and concluding the findings. The research method uses the type of Classroom Action Research. The subjects used in this study were students of class III SDN Central Manarap 1. This study used observation sheet data collection techniques and learning achievement tests. The data obtained were then analyzed descriptively based on the formula and specified criteria. Student activities in learning are dominated by 'good' and 'very good' activities. The mastery of classical learning outcomes $53.57 \%$ achieved at the first and second meetings of $67.86 \%$; third, $78.57 \%$; and fourth, $96.43 \%$. Thus, the Integrated learning model can improve student learning activities and outcomes in the thematic learning of My Hobbies Themes
\end{abstract}

Keywords: hobbies; integrated; thematic learning.

ABSTRAK
Tujuan penelitian ini untuk mengetahui pelaksanaan Integrated yang dicapai setelah
pembelajaran tersebut. Pembelajaran Integrated sebagai strategi yang memfasilitasi siswa untuk
mencari, menemukan konsep-konsep pengetahuan dalam konteks yang nyata atau faktual
namun tetap dibawah bimbingan guru. Langkah-langkah utama dalam kegiatan pembelajaran
Integrated adalah penyajian masalah oleh guru, siswa menetapkan hipotesis, siswa
mengumpulkan data melalui analisis data temuan serta menyimpulkan hasil temuan. Metode
penelitian menggunakan jenis Penelitian Tindakan Kelas. Subjek yang digunakan dalam
penelitian ini adalah siswa kelas III SDN Manarap Tengah 1. Penelitian ini menggunakan teknik
pengumpulan data lembar observasi dan tes hasil belajar. Data yang diperoleh kemudian
dianalisis secara deskriptif berdasarkan rumus dan kriteria yang ditentukan. Aktivitas siswa
pada pembelajaran didominasi keaktifan 'baik' dan 'baik sekali”. Ketuntasan hasil belajar
klasikal 53,57\% dicapai pada pertemuan pertama dan kedua sebesar 67,86\%; ketiga sebesar
$78.57 \%$; dan keempat sebesar 96.43\%. Dengan demikian, model pembelajaran Integrated dapat
meningkatkan aktivitas dan hasil belajar siswa pada pembelajaran tematik Tema Kegemaranku. Kata Kunci : kegemaran; integrated; pembelajaran tematik.

\section{PENDAHULUAN}

Sekolah sebagai institusi resmi yang dikelola oleh pemerintah melaksanakan pendidikan secara terencana, tararah, sistematis, oleh pendidikan profesional dengan program yang dituangkan dalam kurikulum. Adapun jenjangnya yang formal. Idealnya berada pada mereka dalam Slavin (2008:45) mengkategorikan tingkat perkembangan kognitif anak pertama, kedua, 
ketiga berada pada periode operasional konkrit, dan ke empat berada pada periode oprasional formal. Oleh sebab itu, dapat disimpulkan bahwa siswa sekolah dasar berada periode operasional konkrit meskipun mendekati periode perkembangan operasional formal yang belum matang. Siswa dalam tahap operasional konkrit mempunyai karakteristik telah mulai berpikir rasional namun konkrit yang berada pada kegemarannya.

Periode perkembangan siswa sekolah dasar mensyaratkan kebutuhan Kegemaran sekitarnya sebagai dunia belajar yang berhasil. (Suriansyah, 2009:66). Guru dalam mata pelajaran yang diajarkan diharapkan dapat memfasilitasi pengalaman belajar yang melibatkan interaksi aktif dengan dunia konkrit dan faktual sebagai Kegemaran kontekstual yang sesuai dengan proses perkembangan inteligensia dalam mata pelajaran yang diajarkan sesuai untuk perkembangannya. Kegiatan belajar mengajar Tematik di kelas III SDN Manarap Tengah 1 Kecamatan Kertak Hanyar masih banyak menerapkan metode konvensional. Pembelajaran didominasi kegiatan menyimak penjelasan dari guru. Metode ekspositori inipun hanya didukung media sebatas gambar, buku-buku paket dan LKS. Cara belajar Siswa sekolah dasar yang mana membutuhkan kesempatan menemukan dan merekonstruksi pengetahuan dalam pembelajaran yang kontekstual.

Cara belajar demikian cenderung mengalami kegagalan karena pengetahuan yang didapat siswa tidak bertahan lama karena hanya bersifat hafalan yang instan. Pada semester ganjil di tahun pelajaran 2018/2019 untuk ulangan formatif pertama diketahui dari 28 orang siswa hanya 15 orang (53.57\%) yang mendapatkan nilai $\leq 60,00(\mathrm{KKM})$, Sisanya sebanyak 13 orang siswa (46.43\%) memperoleh nilai diatas KKM tersebut sehingga harus dituntaskan dengan beberapa kali remedial.

Nilai siswa telah menggambarkan kurangnya pencapaian kompetensi siswa. Siswa mengalami kesulitan memahami dan mengingat materi pelajaran yang diberikan karena sifatnya hapalan, bukan hasil dari aktivitas belajar aktif karena memang pembelajaran tersebut kurang memberikan kesempatan siswa aktif. Cara belajar ini apabila dibiarkan akan berlanjut berdampak pada prestasi siswa pada mata pelajaran Tematik keseluruhan karena pada dasarnya materi pelajaran itu berkaitan dengan materi. Selain itu akan membentuk paradigma yang salah tentang cara belajar oleh siswa. Siswa akan terpola pada cara belajar yang pasif di pelajaran Tematik itu sendiri bahkan di pelajaran lainnya. Khusus mata pelajaran Tematik sendiri akan terbentuk anggapan bahwa konsep-konsep yang diajarkan tidak memiliki korelasi dengan kehidupan. Prestasi buruk yang terus menerus didapatkan akan membentuk pula anggapan Tematik sebagai mata pelajaran yang sulit.

Oleh sebab itu, diperlukan inovasi strategi pembelajaran yang tepat untuk mengatasi permasalahan diatas. Peneliti memilih tindakan yang akan dilakukan SDN Manarap Tengah 1 Kertak Hanyar Banjar ini model pembelajaran Integrated. Mengingat rendahnya karena minimnya kontekstual, maka model Integrated memberikan ruang kepada guru memberikan bimbingan dan kesempatan belajar. Kelebihan belajar Integrated yang mampu mengakomodasi kesempatan siswa aktif menemukan dan mengkonstruksi pengetahuan dalam konteks yang riil sehingga memungkinkan terjadinya perbaikan hasil belajar. Penelitian bertujuan untuk mengetahui pelaksanaan model pembelajaran Integrated terhadap aktivitas dan hasil belajar siswa pada Tema Kegemaran di kelas III SDN Manarap Tengah 1 Kecamatan Kertak Hanyar Kabupaten Banjar Tahun Pelajaran 2018/2019.

\section{METODE PENELITIAN}

Metode penelitian yang digunakan pada penelitian ini adalah jenis Penelitian Tindakan Kelas. Suatu penelitian yang akar permasalahannya muncul di kelas, oleh dan untuk manfaat kelas (Sholikin, 2008:14). Prinsip dalam pelaksanaan penelitian tindakan kelas, yaitu untuk memperbaiki mutu proses belajar mengajar; menjadi media guru untuk berfikir kritis dan sistematis; menjadikan guru terbiasa melakukan aktivitas yang bernilai akademik; dimulai dari 
permasalahan pembelajaran yang sederhana, konkret; dan tidak boleh terlalu banyak menyita waktu dan terlalu rumit (Kunandar, 2008:67). Tujuan penelitian tindakan kelas, yaitu membantu guru dan tenaga kependidikan lainnya mengatasi masalah pembelajaran, dan meningkatkan professional pendidik dan tenaga kependidikan. Tahap penelitian tindakan kelas menurut Suhardjono (2005) yaitu ada 4 kegiatan utama pada setiap siklusnya. Tahapan tersebut ada pada gambar berikut.

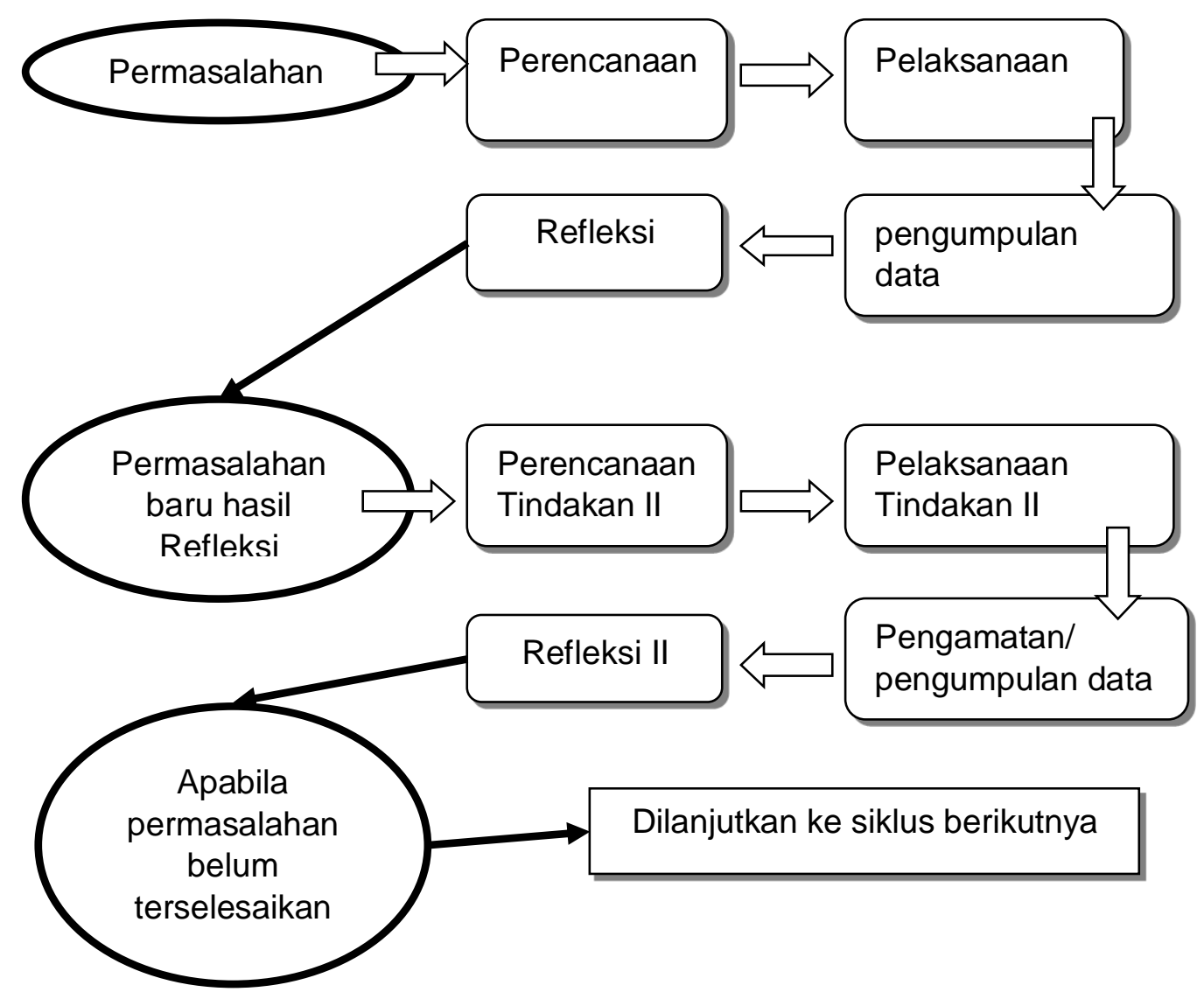

Gambar 1. Tahapan PTK

Waktu pelaksanaan penelitian pada semester genap di kelas III SDN Manarap Tengah 1 dengan jumlah siswa laki-laki 12 orang dan perempuan 16 orang. Pemilihan mata pelajaran didasarkan pada rendahnya prestasi belajar siswa kelas III pada pelajaran Tematik sebelumnya seperti tergambar pada nilai Ulangan Harian Semester III Tahun Pelajaran 2018/2019 yang hanya mencapai nilai rata-rata 53.57\%. Pemilihan pembelajaran Tema Kegemaran didasarkan pada kompleksitas tema yang cukup luas dibandingkan tema lainnya sehingga dialokasikan 16 Jam pelajaran berdasarkan silabus yang dikembangkan sekolah menurut Kurikulum yang berlaku. Kompleksitas tema tersebut dinilai perlu untuk ditingkatkan hasil belajarnya karena akan memiliki kontribusi pada nilai siswa keseluruhan pada semester genap ini. Selain itu dalam beberapa tahun Ujian Nasional yang diselenggarakan, Tema Kegemaran selalu menjadi salah satu indikator dalam standar kompetensi lulusan (SKL) untuk mata pelajaran tematik sehingga perlu untuk mendapat perhatian.

Faktor siswa yang diteliti yaitu aktivitas siswa kelas III SDN Manarap Tengah 1 Kecamatan Kertak Hanyar Kabupaten Banjar Tahun Pelajaran 2018/2019 dalam pembelajaran Tema Kegemaran melalui model Integrated. Aktivitas siswa yang diteliti yakni meliputi aktivitas perorangan siswa dalam merespon masalah yang disajikan, menentukan hipotesis, melakukan persiapan dan melaksanakan diskusi serta menganalisa hasil diskusi, menyimpulkan 
hasil kegiatan dan mempresentasikannnya. Keaktifan siswa dinilai menggunakan lembar observasi aktivitas siswa. Selain keaktifan, hasil belajar juga diukur melalui tes hasil belajar dalam pembelajaran Integrated tiap pertemuan.

Data hasil bersumber dari aktivitas siswa serta tes dalam tiap pertemuan pelaksanaan tindakan. Pengelolaan observasi keaktifannya adalah bersumber dari nilai akhir pertemuan. Data aktivitas guru dan siswa diambil melalui lembar observasi. Untuk pengolahan data dilakukan dengan rumus:

$$
\text { Aktivitas }=\frac{\text { Jumlah skor }}{\text { Jumlah skor Keseluruha } \mathrm{n}} \times 100 \%
$$

Selain itu dengan memberikan tes tertulis kepada siswa setiap akhir pertemuan. Nilai tes akhir diolah kemudian disesuaikan dengan kriteria berikut:

Kriteria ketuntasan belajar (BSNP Depdiknas, 2007:30):

a. KKM Sekolah

b. $\geq 75 \%$ individual

Keberhasilan Tindakan Kelas diukur pada tiap pertemuan pelaksanaan tindakan. Pelaksanaan tindakan dinyatakan berhasil apabila tiap pertemuan dicapai indikator:

a. Pada tiap pertemuan aktivitas siswa minimal pada kualifikasi keaktifan 'baik' dengan persentase mencapai $\geq 75 \%$.

b. Ketuntasan secara individual dikatakan tercapai apabila diperoleh nilai $\geq 60$ sebagaimana kriteria ketuntasan belajar minimal yang ditetapkan sekolah tempat penelitian. Ketuntasan hasil belajar secara klasikal apabila siswa yang memperoleh ketuntasan individual (mendapat nilai $\geq 60$ ) mencapai $\geq 80 \%$ dari jumlah siswa yang terlibat dalam pembelajaran.

\section{HASIL PENELITIAN DAN PEMBAHASAN}

\section{A. Hasil Penelitian}

\section{Pelaksanaan Tindakan Kelas pada Siklus I}

Pada siklus I, pembelajaran integrated dilaksanakan di kelas III SDN Manarap Tengah 1 Kertak Hanyar Banjar dengan dua kali pertemuan. Berikut gambaran pelaksanaan pembelajaran integrated siklus I.

\section{a. Pelaksanaan Tindakan}

Pada pembelajaran pertemuan pertama, guru melaksanakan pembelajaran sesuai dengan rencana yang telah disusun. Dimulai dengan membentuk kelompok, kemudian menyajikan pelajaran dengan menggunakan alat bantu atau media pembelajaran. Siswa diarahkan untuk memperhatikan penjelasan guru pada saat menerangkan materi pembelajaran. Setelah itu, guru mengaktifkan siswa dengan memberi tugas kepada setiap individu dalam kelompok dan membimbing siswa dalam mengerjakan tugas sesuai kemampuannya. Kemudian, tugas yang sudah dikerjakan secara berkelompok didiskusikan dan dibahas. Guru memberi menyampaikan kerja memberikan penghargaan yang mendapatkan nilai tertinggi. Guru dan siswa menyimpulkan pembelajaran yang telah dilaksanakan.

Pada pertemuan kedua, guru juga melaksanakan pembelajaran sesuai dengan rencana yang telah disusun. Guru membentuk kelompok secara heterogen. Selama pembagian kelompok ini suasana sedikit kacau dan gaduh, karena rata-rata siswa ingin sekelompok dengan teman pilihannya sendiri. Namun, suasana ini tidak terjadi berlarut-larut serta dapat dikembalikan kondusif seperti semula. Setelah selesai teman masing-masing, diarahkan curah pendapat dalam permasalahan yang diajukan guru. Setelah kelompok selesai melakukan kegiatan, kemudian guru memberikan dari kegiatan yang dilakukan membacakan hasil kerjanya di depan kelas, sementara mendengarkan dan terhadap menyampaikan kegiatan, baik berupa pertanyaan ataupun tambahan pendapat guna melengkapi hasil. Kemudian meminta siswa untuk mengembalikan alat kelompoknya ke depan (meja guru) dan meminta siswa untuk 
merapikan seperti dan ketempat seperti semula. Bersama-sama siswa membuat kesimpulan dengan memberikan pertanyaan-pertanyaan kepada siswa yang telah juga agar mengingatnya.

b. Observasi

1) Hasil Observasi Aktivitas Siswa

Selama pembelajaran integrated pada tema kegemaranku, dilakukan observasi pada aktivitas siswa dalam pertemuan 1 dan 2 siklus I. Berikut hasil observasi aktivitas siswa siklus I.

Tabel 1. Hasil Observasi Aktivitas Siswa Siklus I

\begin{tabular}{|c|l|c|c|c|c|}
\hline \multirow{2}{*}{ No } & \multirow{2}{*}{ Kategori } & \multicolumn{2}{c|}{ Pertemuan 1 } & \multicolumn{2}{c|}{ Pertemuan 2 } \\
\cline { 3 - 6 } & & Frekuensi & Presentasi & Frekuensi & Presentasi \\
\hline 1 & Aktif sekali & 7 & $25 \%$ & 9 & $32.14 \%$ \\
\hline 2 & Aktif & 8 & $28.57 \%$ & 8 & $28.57 \%$ \\
\hline 3 & Cukup aktif & 6 & $21.43 \%$ & 6 & $21.43 \%$ \\
\hline 4 & Kurang aktif & 7 & $25 \%$ & 5 & $17.86 \%$ \\
\hline \multicolumn{2}{|c|}{ Ketuntasan } & \multicolumn{2}{|c|}{$53,57 \%$} & \multicolumn{2}{c|}{$60,71 \%$} \\
\hline
\end{tabular}

Berdasarkan tabel tersebut, pada pertemuan pertama, ketuntasan aktivitas siswa sebanyak $53,57 \%$ dan meningkat pada pertemuan kedua menjadi $60,71 \%$. Pada pertemuan pertama, sebanyak 7 siswa yang aktif sekali dan 8 siswa yang aktif, serta 6 siswa cukup aktif dan 7 siswa kurang aktif. Sedangkan pertemuan kedua, sebanyak 9 siswa yang aktif sekali, 8 siswa aktif, 6 siswa cukup aktif, dan 5 siswa kurang aktif.

\section{2) Hasil Belajar Siswa}

Selama pembelajaran integrated pada tema kegemaranku, dilakukan tes hasil belajar siswa pada setiap pertemuan di siklus I. Berikut hasil belajar siswa pada siklus I.

Tabel 2. Hasil Belajar Siswa Siklus I

\begin{tabular}{|c|c|c|c|c|c|c|c|}
\hline \multirow{2}{*}{ No } & \multirow{2}{*}{ Nilai } & \multicolumn{3}{|c|}{ Pertemuan 1} & \multicolumn{3}{|c|}{ Pertemuan 2} \\
\hline & & Frekuensi & Tuntas & TidakTuntas & Frekuensi & Tuntas & TidakTuntas \\
\hline 1 & 100 & 3 & $10.71 \%$ & - & 5 & $17.86 \%$ & - \\
\hline 2 & 90 & 4 & $14.29 \%$ & - & 5 & $17.86 \%$ & - \\
\hline 3 & 80 & 4 & $14.29 \%$ & - & 5 & $17.86 \%$ & - \\
\hline 4 & 70 & 4 & $14.29 \%$ & - & 5 & $17.86 \%$ & - \\
\hline 5 & 60 & 6 & & $21.43 \%$ & 4 & & $14.29 \%$ \\
\hline 6 & 50 & 7 & & $25 \%$ & 4 & & $14.29 \%$ \\
\hline 7 & 40 & 0 & $0 \%$ & - & 0 & & $0 \%$ \\
\hline \multicolumn{3}{|c|}{$\begin{array}{c}\text { Jumlah } \\
\text { Ketuntasan Klasikal }\end{array}$} & $53.57 \%$ & $46.43 \%$ & & $78.57 \%$ & $21.43 \%$ \\
\hline
\end{tabular}

Pada pertemuan pertama, sebanyak 15 siswa $(53,57 \%)$ yang dapat dikatakan tuntas belajar, sedangkan 13 siswa $(46,63 \%)$ belum tuntas belajar. Pada pertemuan kedua, jumlah siswa yang tuntas belajar meningkat menjadi 78,57\% atau sebanyak 20 orang. Untuk 8 orang lainnya dinyatakan belum tuntas belajar.

Al-Adzka: Vol. 9, No. 2, Desember 2019 


\section{c. Refleksi}

Dalam pelaksanaan pembelajaran, menunjukkan persentase klasikal aktivitas siswa sebesar 53.57\% dengan jumlah siswa yang berada pada keterangan aktif adalah 15 orang. Hal ini menunjukkan belum sepenuhnya pembelajaran dilaksanakan oleh siswa secara optimal atau ketercapaian. Berdasarkan aktivitas dikatakan berhasil apabila berada pada kategori minimal aktif, dan persentase keaktifan klasikal siswa $\geq 80 \%$. Siswa kelihatan masih kurang mampu bekerja sama dengan anggota kelompoknya karena siswa terbiasa melaksanakan tugas secara individu. Dalam kegiatan curah pendapat mengenai permasalahan maupun dalam memberikan tanggapan dorongan. Pada siklus I pertemuan 1 ini, siswa yang mendapatkan nilai $\geq 70$ atau yang dinyatakan tuntas adalah 15 orang. Berdasarkan indikator ketuntasan hasil belajar yang ditetapkan, berhasil dalam nilai $\geq 70$ dan klasikal $\geq 80 \%$. Persentase ketuntasan klasikal siswa pada siklus I pertemuan 1 ini hanya mencapai 53.57\%. Artinya, hasil belajar siswa belum mencapai target.

Selain itu, pertemuan ini banyak melakukan curah pendapat, mencari informasi melalui diskusi tersebut, serta proses diskusi dan tanya jawab yang masih kurang, dikarenakan siswa kurang percaya diri atau malu-malu dalam mengemukakan pendapatnya. Ini disebabkan siswa masih terbiasa dengan gaya belajar lama, bekerja secara kelompok, yang berdampak dalam pertemuan selanjutnya, bisa meningkatkan interaksi antar siswa dalam bekerja sama secara kelompok dan juga memberikan motivasi pada siswa atau dorongan agar lebih memiliki sikap percaya diri dalam mengemukakan pendapatnya.

Pada pertemuan kedua, pelaksanaan pembelajaran menunjukkan $60.71 \%$ jumlah siswa yang berada pada keterangan aktif adalah 17 orang, secara klasikal aktifitas siswa berada pada kategori cukup aktif. Hal ini menunjukkan aktivitas siswa dalam pembelajaran belum sepenuhnya dilaksanakan siswa secara optimal atau ketercapaian. Berdasarkan aktivitas dikatakan berhasil apabila berada pada kategori minimal aktif, dan persentase keaktifan klasikal siswa $\geq 80 \%$. Tergolong siswa kelihatan masih kurang mampu bekerja sama dengan anggota kelompoknya karena siswa terbiasa melaksanakan tugas secara individu. Dalam kegiatan curah pendapat mengenai permasalahan maupun terlihat dalam memberikan tanggapan atau atau dorongan

Pada siklus I pertemuan 2 ini, siswa yang mendapatkan nilai $\geq 70$ atau yang dinyatakan tuntas adalah 20 orang. Berdasarkan indikator ketuntasan hasil belajar yang ditetapkan, berhasil dalam nilai $\geq 70$ dan klasikal $\geq 80 \%$. Persentase ketuntasan klasikal siswa pada siklus I pertemuan 2 ini hanya mencapai $71.43 \%$. artinya belum tuntas. Selain itu, pertemuan ini banyak oleh aktivitas sukar dalam melakukan curah pendapat, mencari informasi melalui diskusi tersebut, serta proses diskusi dan tanya jawab yang masih kurang, dikarenakan siswa kurang percaya diri atau malu-malu dalam mengemukakan pendapatnya. Ini disebabkan siswa masih terbiasa dengan gaya belajar lama, bekerja secara kelompok, yang berdampak. Dalam pertemuan selanjutnya, bisa meningkatkan interaksi antar siswa dalam bekerja sama secara kelompok dan juga memberikan motivasi pada siswa atau dorongan agar lebih memiliki sikap percaya diri dalam mengemukakan pendapatnya.

\section{Pelaksanaan Tindakan Kelas pada Siklus II}

Pada siklus II, pembelajaran integrated dilaksanakan di kelas III SDN Manarap Tengah 1 Kertak Hanyar Banjar dengan dua kali pertemuan. Berikut gambaran pelaksanaan pembelajaran integrated siklus II.

\section{a. Pelaksanaan Tindakan}


Pada pertemuan ketiga dan keempat, tidak jauh berbeda dengan pertemuan-pertemuan sebelumnya, guru membentuk 7 kelompok. Kemudian guru juga mengarahkan siswa untuk berkelompok dan menjelaskan bahwa keberhasilan individu tergantung dari keberhasilan kelompok. Guru meminta siswa mengerjakan tugas sesuai kempuannya kemudian tugas yang sudah dikerjakan, didiskusikan bersama-sama dengan kelompok lain. Siswa secara berkelompok bergantian dalam maju ke depan kelas menyampaikan hasil diskusinya. Kemudian diberikan penghargaan untuk kelompok yang mendapatkan nilai tertinggi. Bersamasama dengan siswa menyimpulkan pembelajaran yang telah dilaksanakan. Guru memberi pertanyaan-pertanyaan kepada beberapa siswa seputar materi yang dipelajari, Kemudian guru memberikan soal evaluasi. Setelah evaluasi selesai, guru menutup pelajaran dengan memberikan nasehat dan terakhir.

\section{b. Observasi}

\section{1) Hasil Observasi Aktivitas Siswa}

Selama pembelajaran integrated pada tema kegemaranku, dilakukan observasi pada aktivitas siswa dalam pertemuan 1 dan 2 siklus II. Berikut hasil observasi aktivitas siswa siklus II.

Tabel 3. Hasil Observasi Aktivitas Siswa Siklus II

\begin{tabular}{|c|l|c|c|c|c|}
\hline \multirow{2}{*}{ No } & \multirow{2}{*}{ Kategori } & \multicolumn{2}{c|}{ Pertemuan 1 } & \multicolumn{2}{c|}{ Pertemuan 2 } \\
\cline { 3 - 6 } & & Frekuensi & Persentase & Frekuensi & Persentase \\
\hline 1 & Aktif sekali & 10 & $35.71 \%$ & 13 & $46.43 \%$ \\
\hline 2 & Aktif & 10 & $35.71 \%$ & 13 & $46.43 \%$ \\
\hline 3 & Cukup aktif & 4 & $14.29 \%$ & 2 & $7.14 \%$ \\
\hline 4 & Kurang aktif & 4 & $14.29 \%$ & 0 & $0 \%$ \\
\hline \multicolumn{2}{|c|}{ Ketuntasan } & \multicolumn{2}{|c|}{$71.43 \%$} & \multicolumn{2}{c|}{$92.86 \%$} \\
\hline
\end{tabular}

Berdasarkan tabel tersebut, pada pertemuan ketiga, ketuntasan aktivitas siswa sebanyak $71,43 \%$ dan meningkat pada pertemuan keempat menjadi 92,86\%. Pada pertemuan ketiga, sebanyak 10 siswa yang aktif sekali dan 10 siswa yang aktif, serta 4 siswa cukup aktif dan 4 siswa kurang aktif. Sedangkan pertemuan keempat, sebanyak 13 siswa yang aktif sekali, 13 siswa aktif, 2 siswa cukup aktif, dan 0 siswa kurang aktif.

\section{2) Hasil Belajar Siswa}

Selama pembelajaran integrated pada tema kegemaranku, dilakukan tes hasil belajar siswa pada setiap pertemuan di siklus II. Berikut hasil belajar siswa pada siklus II.

Tabel 4. Hasil Belajar Siswa Siklus II

\begin{tabular}{|c|c|c|c|c|c|c|c|}
\hline \multirow{2}{*}{ No } & \multirow{2}{*}{ Nilai } & \multicolumn{4}{|c|}{ Pertemuan 1 } & \multicolumn{3}{c|}{ Pertemuan 2 } \\
\cline { 3 - 8 } & & Frekuensi & Tuntas & $\begin{array}{c}\text { Tidak } \\
\text { Tuntas }\end{array}$ & Frekuensi & Tuntas & $\begin{array}{c}\text { Tidak } \\
\text { Tuntas }\end{array}$ \\
\hline 1 & 100 & 6 & $21.43 \%$ & - & 7 & $25 \%$ & - \\
\hline 2 & 90 & 6 & $21.43 \%$ & - & 7 & $25 \%$ & - \\
\hline 3 & 80 & 5 & $17.86 \%$ & - & 7 & $25 \%$ & - \\
\hline 4 & 70 & 5 & $17.86 \%$ & - & 6 & $21.43 \%$ & - \\
\hline 5 & 60 & 3 & & $10.71 \%$ & 1 & & $3.57 \%$ \\
\hline 6 & 50 & 3 & & $10.71 \%$ & 0 & & $0 \%$ \\
\hline
\end{tabular}




\begin{tabular}{|c|c|c|c|c|c|c|c|}
\hline 7 & 40 & 0 & & $0 \%$ & 0 & & $0 \%$ \\
\hline & Jum & sikal & $78.57 \%$ & $21.43 \%$ & & $96.43 \%$ & $3.57 \%$ \\
\hline
\end{tabular}

Pada pertemuan ketiga, sebanyak 22 siswa $(78,57 \%)$ yang dapat dikatakan tuntas belajar, sedangkan 6 siswa $(21,43 \%)$ belum tuntas belajar. Pada pertemuan keempat, jumlah siswa yang tuntas belajar meningkat menjadi 96,43\% atau sebanyak 27 orang. Untuk 1 orang lainnya dinyatakan belum tuntas belajar.

\section{c. Refleksi}

Pada pertemuan ketiga ini, aktivitas siswa memperoleh kategori aktif dan ketuntasan klasikalnya $71.43 \%$. Hampir rata-rata sudah mulai aktif, hanya saja masih aktif dalam diantaranya seperti aspek bekerjasama secara aktif dengan teman sekelompoknya, kerena dalam proses pembelajaran masih terlihat beberapa siswa yang hanya diam saja menunggu jawaban dari temannya. Harapannya, guru harus lebih baik lagi memberikan arahan bahwa keberhasilan siswa tergantung dari keberhasilan kelompok, sehingga siswa dapat antusias dalam kerja kelompok. Pada pertemuan ini, 22 orang siswa yang memperoleh nilai ketuntasan yaitu dengan persentase $78.57 \%$. Keterlibatan guru dalam pertemuan ini sudah lebih baik sehingga dapat, hanya saja nilainya masih dibawah yang ditetapkan. Meskipun belum dapat mencapai hasil yang maksimal, akan tetapi hasil tersebut sudah cukup memuaskan.

Pada pertemuan keempat, aktivitas siswa memperoleh kategori sangat aktif dengan ketuntasan klasikalnya $92.86 \%$, dan telah mencapai dari indikator yang telah ditetapkan sebelumnya. Pada pertemuan ini terdapat peningkatan hampir semua dibuktikannya dengan peningkatan aktivitas siswa disetiap pertemuannya. Pada pertemuan ini 27 orang siswa yang memperoleh nilai ketuntasan yaitu dengan persentase $96.43 \%$. Pada pembelajaran ini, siswa sudah mulai memahami materi, dibuktikannya dengan nilai hasil tes ketuntasan klasikal $96.43 \%$, sehingga hasil belajar telah tercapai.

\section{B. Pembahasan}

Pada hasil penelitian 1, 2, 3 dan 4 terdapat adanya peningkatan baik pada aktivitas. Secara keseluruhan tabel 5 dibawah ini:

Tabel 5 Perbandingan Aktivitas dan Hasil Belajar Siswa

\begin{tabular}{|c|c|c|c|c|c|}
\hline No & Aspek & $\mathbf{1}$ & $\mathbf{2}$ & $\mathbf{3}$ & $\mathbf{4}$ \\
\hline 1 & Aktivitas Siswa & $53.57 \%$ & $60.71 \%$ & $71.43 \%$ & $92.86 \%$ \\
\hline 2 & Hasil Belajar & $53.57 \%$ & $71.43 \%$ & $78.57 \%$ & $96.43 \%$ \\
\hline
\end{tabular}

Berdasarkan Tabel 5 terlihat adanya peningkatan pada aktivitas Pertemuan 1, Pertemuan 2, Pertemuan 3 dan Pertemuan 4 yang menunjukkan perolehan nilai aktivitas batasan nilai, dan hasil belajar siswanya pun telah mencapai indikator. Dengan demikian, proses pembelajaran dengan menerapkan Model Integrated dapat dikatakan berhasil.

Berdasarkan hasil observasi aktivitas siswa, persentase pada aktivitasnya meningkat setiap pertemuan. Hal ini dikarenakan, guru berusaha memperhatikan memperbaiki aktivitas yang telah dilakukan pada pertemuan sebelumnya agar pembelajaran menjadi lebih efektif. Upaya perbaikan ini dilakukan guru dengan merencanakan kembali strategi-strategi untuk pembelajaran berikutnya berdasarkan refleksi dari pertemuan sebelumnya. Aspek-aspek yang belum dilaksanakan secara maksimal dipertemuan sebelumnya dicatat dan diidentifikasi kekurangan-kekurangan dalam pelaksanaannya sehingga guru dapat menemukan solusi untuk 
meminimalisir kekurangan tersebut agar pada pertemuan berikutnya pembelajaran dapat dilaksanakan lebih baik lagi.

Analisis data Tematik Tema Kegemaran menggunakan Model Pembelajaran Integrated pada kelas III SDN Manarap Tengah 1 Kecamatan Kertak Hanyar Kabupaten Banjar Tahun Pelajaran 2018/2019, baik pada siklus I maupun aktivitas ditiap pertemuannya bahkan pertemuan 2 secara klasikal tergolong sangat aktif. Keaktifan pembelajaran ditunjukkan pula oleh siswa yang senang dan bersemangat dalam kegiatan belajar. Mereka aktif mengemukakan pendapatnya dalam diskusi kelompok serta bersemangat untuk melakukan kegiatan yang cocok. sejalan.

Suriansyah, dkk (2010: 263) menyatakan bahwa indikator keterlibatan siswa dalam pembelajaran dapat dilihat melalui pembelajaran. Oleh sebab itu, model Integrated dapat membuat belajar mengajar menjadi semakin aktif. Adanya siswa pembelajaran Integrated. Penerapan Integrated dapat meningkatkan pemahaman siswa sesuai dengan hasil penelitian yang dilakukan oleh Hariadi (2012) bahwa model integrated dapat meningkatkan rata-rata kelas daro 65\% menjadi 93\%. Selain itu, menurut Husna (2012), menyatakan bahwa mode pembelajaran integrated dapat meningkatkan hasil belajar dari 60,50\% menjadi $90 \%$. Dengan demikian, penerapan model pembelajaran Integrated pada Tema Kegemaran pada kelas III SDN Manarap Tengah 1 Kecamatan Kertak Hanyar Kabupaten Banjar Tahun Pelajaran 2018/2019 dinyatakan berhasil.

\section{PENUTUP}

Berdasarkan hasil penelitian dan pembahasan dalam penelitian ini dapat disimpulkan bahwa aktivitas siswa pada pembelajaran didominasi keaktifan 'baik' dan 'baik sekali'. Ketuntasan hasil belajar klasikal 53,57\% dicapai pada pertemuan pertama dan kedua sebesar 67,86\%; ketiga sebesar $78.57 \%$; dan keempat sebesar $96.43 \%$.

\section{DAFTAR PUSTAKA}

Arikunto, Suharsimi, dkk. 2006. Penelitian Tindakan Kelas. Jakarta: Bumi Aksara.

BNSP. 2007. Permendiknas RI Nomor 41 tahun 2007 Standar Proses untuk Satuan Pendidikan Dasar dan Menengah. Jakarta: Depdiknas.

Hariadi. 2012. Meningkatkan Hasil Belajar Siswa Tema Diri Sendiri di Kelas III SDN Banjarbaru Kota 4. Skripsi: Universitas Lambung Mangkurat (tidak dipublikasikan). http://akhmadsudrajat.wordpress.com/2011/01/30/pembelajaran-tematik/ diakses 10 Juli 2017.

Husna. 2012. Meningkatkan Hasil Belajar Siswa Budi Pekerti di Kelas III SDN Banjarbaru Utara 1. Skripsi: Universitas Lambung Mangkurat (tidak dipublikasikan).

Kunandar. 2008. Langkah Mudah Penelitian Tindakan Kelas. Jakarta: Rajawali Pers.

Pemerintah RI. 2006. Undang-undang Republik Indonesia Nomor 20 Tahun 2003 Tentang Sistem Pendidikan Nasional. Jakarta: Citra Umbara.

Slavin, R.E. 1995. Cooperative Learning Theory Research and Practice Second Edition. Massachhusetts: Allyn dan Bacon.

Suhardjono. 2005. Laporan Penelitian Eksperimen dan Penelitian Tindakan Kelas sebagai KTI. Jakarta: Pelatihan Peningkatan Mutu Guru Makasar.

Suriansyah, Ahmad, dkk. 2009. Strategi Pembelajaran. Banjarmasin: Universitas Lambung Mangkurat.

Undang-Undang Nomor 20 tahun 2003 Tentang Sistem Pendidikan Nasional. Yogyakarta: Pustaka Pelajar. 
Rohana 